\title{
Nitrous oxide emissions from an apple orchard soil in the semiarid Loess Plateau of China
}

\author{
Junzhu Pang • Xiaoke Wang • Yujing Mu • \\ Zhiyun Ouyang $\cdot$ Wenzhao Liu
}

Received: 5 May 2009 /Revised: 26 August 2009 /Accepted: 27 August 2009 /Published online: 16 September 2009

(C) Springer-Verlag 2009

\begin{abstract}
Nitrous oxide $\left(\mathrm{N}_{2} \mathrm{O}\right)$ fluxes from an apple orchard soil in the semiarid Loess Plateau of China were measured using static chambers from September 2007 to September 2008. In this study, three sites were selected at distance of $2.5 \mathrm{~m}$ (D 2.5), $1.5 \mathrm{~m}$ (D 1.5), and $0.5 \mathrm{~m}$ (D 0.5) from the apple tree row. Nitrous oxide fluxes followed seasonal pattern, with high $\mathrm{N}_{2} \mathrm{O}$ emission rates occurring in the hot-humid summer and low rates in the cold-dry winter. Pulses of $\mathrm{N}_{2} \mathrm{O}$ emissions occurred after nitrogen fertilizer application, summer rainfall events, and during freeze-thaw cycles. Annual average $\mathrm{N}_{2} \mathrm{O}$ emission rates were the highest at D 0.5 site $\left(48.2 \pm 39.9 \mu \mathrm{g} \mathrm{N}_{2} \mathrm{O} \mathrm{m}^{-2} \mathrm{~h}^{-1}\right)$, the lowest at D 2.5 site $\left(31.9 \pm 18.2 \mu \mathrm{g} \mathrm{N}_{2} \mathrm{O} \mathrm{m}^{-2} \mathrm{~h}^{-1}\right)$, and intermediate at D1.5 site $\left(36.8 \pm 32.2 \mu \mathrm{g} \mathrm{N}_{2} \mathrm{O} \mathrm{m}^{-2} \mathrm{~h}^{-1}\right)$, suggesting that $\mathrm{N}_{2} \mathrm{O}$ emissions from the apple orchard soil increased when the chamber location was closer to the apple tree row. This may be due to the fertilization close to roots in hot and humid season. Over one third (37.1\%) of the annual $\mathrm{N}_{2} \mathrm{O}$ emission occurred in the summer. Annual $\mathrm{N}_{2} \mathrm{O}$ emissions from the apple orchard soil averaged to $3.22 \mathrm{~kg} \mathrm{~N}_{2} \mathrm{O} \mathrm{ha}{ }^{-1}$ year $^{-1}$. Annual emission factor of the apple orchard from the applied fertilizer (uncorrected for background emission) was $0.658 \%$. This value was nearly a half $(53 \%)$ of the default value provided by the Intergovernmental Panel on Climate
\end{abstract}

J. Pang $\cdot X$. Wang $(\bowtie) \cdot Y$. Mu $\cdot$ Z. Ouyang

State Key Lab of Urban and Regional Ecology,

Research Center for Eco-Environmental Sciences,

Chinese Academy of Sciences,

Shuangqinglu 18,

Beijing 100085, China

e-mail: wangxk@rcees.ac.cn

W. Liu

Institute of Soil and Water Conservation,

Chinese Academy of Sciences,

Yangling 712100, China
Change for the application of synthetic fertilizers to cropland (1.25\%). Therefore, the amount of $\mathrm{N}_{2} \mathrm{O}$ emissions from the semiarid apple orchard soil could be largely overestimated if no regional-specific factor is used.

Keywords Nitrous oxide emission · Apple orchard soil · Nitrogen fertilizer - Emission factor · China · Loess Plateau

\section{Introduction}

Nitrous oxide $\left(\mathrm{N}_{2} \mathrm{O}\right)$ is a relatively stable greenhouse gas that also contributes to ozone layer destruction in the stratosphere. Agricultural soils are known to be responsible for a large proportion $(70-81 \%)$ of the increase in $\mathrm{N}_{2} \mathrm{O}$ emissions to the atmosphere, mainly due to the use of nitrogen fertilizer (Mosier et al. 1996; Dobbie et al. 1999; Weitz et al. 2001; Dobbie and Smith 2003; Stehfest and Bouwman 2006; Barton et al. 2007). Despite an increase in the number of $\mathrm{N}_{2} \mathrm{O}$ measurements from agricultural soils in recent years, there is still a great deal of uncertainty in the current estimates of the total global $\mathrm{N}_{2} \mathrm{O}$ emission, and the average $95 \%$ confidence interval for calculating $\mathrm{N}_{2} \mathrm{O}$ emission was $-51 \%$ to $+107 \%$ (Stehfest and Bouwman 2006). Semiarid and arid lands constitute a large part of the global land area and are widely used for agricultural production. So far, the magnitude of the contribution of rain-fed semiarid agricultural soils to the global sources of $\mathrm{N}_{2} \mathrm{O}$ is based only on the contribution by Barton et al. (2007) who measured $\mathrm{N}_{2} \mathrm{O}$ in south-western Australia, reporting an annual $\mathrm{N}_{2} \mathrm{O}$ emissions from 0.09 to $0.11 \mathrm{~kg} \mathrm{ha}^{-1}$ and the emission factor of $0.02 \%$, which was 60 times lower than the Intergovernmental Panel on Climate Change (IPCC) default value (Barton et al. 2007). In China, 43.1\% of the land area is located in semiarid or arid climatic zones 


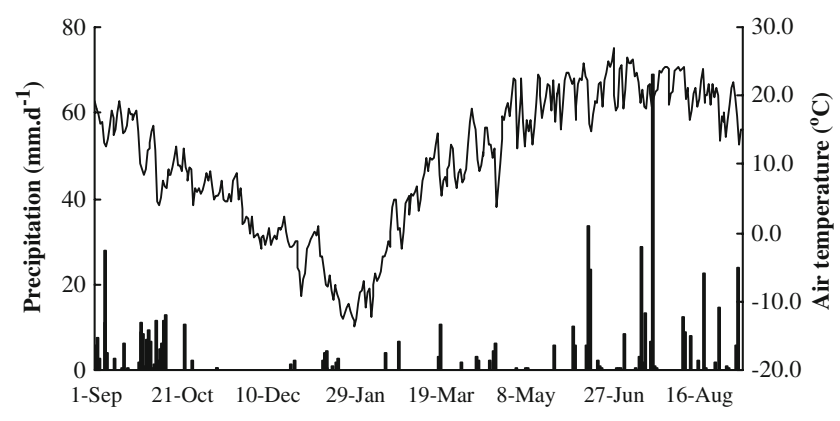

Fig. 1 Daily mean air temperature and precipitation in Changwu Agri-ecological Station, Loess Plateau of China

and is extensively used for agricultural production, but $\mathrm{N}_{2} \mathrm{O}$ emissions from these croplands are not available (Zheng et al. 2004; Lu et al. 2006).

The Loess Plateau, which covers nearly $4.30 \times 10^{5} \mathrm{~km}^{2}$ in northwest China, is characterized by arid conditions and high soil erosion. The mean temperature and annual precipitation are in ranges of $3.6-14.3^{\circ} \mathrm{C}$ and 150 $750 \mathrm{~mm}$, respectively. In order to reduce soil erosion and increase farmer income, apple orchards were established on a large area $\left(34^{\circ}-37^{\circ} \mathrm{N}\right)$ since the 1970 s (Wu et al. 2008). Apple orchards cover an area of approximately $4.69 \%$ of the cultivated area in the Loess Plateau (about $7.83 \times$ $10^{5} \mathrm{ha}$ ) and account for more than $62.0 \%$ of agricultural land in the study area (Wangdong Gou watershed, Li personal communication).

Nitrous oxide is mainly produced in soil by nitrification and denitrification, which are particularly controlled by soil water-filled pore space (WFPS), soil temperature, availability of labile organic carbon, soil $\mathrm{pH}$, and the proportion and amount of ammonium and nitrate present (Bouwman 1998; Davidson et al. 2000; Dobbie and Smith 2003; Martin et al. 2003). In the apple orchards, these factors are strongly controlled by fertilizer management, weed control practices, and the phenology of the apple trees, which all had large impacts on $\mathrm{N}$ dynamics in the apple orchard soils (Hoagland et al. 2008). In addition, compared with the cropland in this region, the apple orchards are always fertilized more than one time at high rates in different sites. The estimation of $\mathrm{N}_{2} \mathrm{O}$ emission from apple orchard soil is needed to calculate the annual emission of $\mathrm{N}_{2} \mathrm{O}$ in the Loess Plateau region.

The objectives of this study were therefore to determine the temporal variations of $\mathrm{N}_{2} \mathrm{O}$ fluxes from an apple orchard soil in the Loess Plateau and to investigate its relationship to soil and environmental factors, such as air temperature, soil moisture, and fertilization.

\section{Materials and methods}

Experimental site and soils

The study was conducted at the Changwu Agri-ecological Station, Loess Plateau $\left(107^{\circ} 41^{\prime} \mathrm{E}, 35^{\circ} 14^{\prime} \mathrm{N}, 1,200 \mathrm{~m}\right.$ above sea level) in Changwu County, Shaanxi Province, China. The investigated area is representative of the gully terrain in the Loess Plateau, and the climate is classified as semiarid, with annual average precipitation of $565 \mathrm{~mm}$, of which nearly $49 \%$ occurs from July to September. The annual mean temperature $(1984-2004)$ is $9.1^{\circ} \mathrm{C}$, and there are about 171 frost-free days each year (Fig. 1). The soil is a coarse-textured dark loessial soil. The main characteristics of the soil at the depth of $0-40 \mathrm{~cm}$ are: soil organic carbon 4.05-6.55 $\mathrm{g} \mathrm{kg}^{-1}$, total nitrogen $0.86-1.09 \mathrm{~g} \mathrm{~kg}^{-1}$, available phosphorus $3.0 \mathrm{mg} \mathrm{kg}^{-1}$, $\mathrm{pH} 7.87-8.55$, bulk density 1.19 $1.30 \mathrm{~g} \mathrm{~cm}^{-1}$, mineral nitrogen $1.39-1,114 \mu \mathrm{g} \mathrm{g}^{-1}$, and clay content $24 \%(<0.002 \mathrm{~mm}$; Table 1$)$.

Experimental design

The apple orchard (which was converted from the former winter wheat field in 1984) was dominated by Fuji apple trees
Table 1 The main physiochemical characteristics of soil

The soil parameters were given by mean \pm standard deviations of five soil samples collected in June 2008 according to standard methods. The D 2.5, D 1.5, and D 0.5 were the measuring sites $2.5,1.5$, and $0.5 \mathrm{~m}$ from apple tree row, respectively

\begin{tabular}{lrlll}
\hline Parameters & Soil layer $(\mathrm{cm})$ & \multicolumn{2}{l}{ Measuring sites } \\
\cline { 3 - 6 } & & $\mathrm{D} 2.5$ & $\mathrm{D} 1.5$ & $\mathrm{D} 0.5$ \\
\hline Soil organic carbon $\left(\mathrm{g} \mathrm{kg}^{-1}\right)$ & $0-10$ & $6.55 \pm 0.14$ & $6.00 \pm 0.09$ & $6.22 \pm 0.94$ \\
& $10-20$ & $4.72 \pm 0.59$ & $4.95 \pm 0.08$ & $4.42 \pm 0.20$ \\
& $20-40$ & $4.05 \pm 0.10$ & $5.19 \pm 0.20$ & $5.28 \pm 1.12$ \\
Total nitrogen $\left(\mathrm{g} \mathrm{kg}^{-1}\right)$ & $0-10$ & $1.01 \pm 0.02$ & $1.02 \pm 0.02$ & $1.05 \pm 0.01$ \\
& $10-20$ & $0.89 \pm 0.01$ & $1.04 \pm 0.03$ & $0.89 \pm 0.01$ \\
pH $\left(\mathrm{H}_{2} \mathrm{O}\right)$ & $20-40$ & $0.91 \pm 0.05$ & $1.09 \pm 0.04$ & $0.86 \pm 0.02$ \\
& $0-10$ & $8.49 \pm 0.02$ & $8.19 \pm 0.01$ & $8.30 \pm 0.01$ \\
Bulk density $\left(\mathrm{g} \mathrm{cm}^{-3}\right)$ & $10-20$ & $8.55 \pm 0.01$ & $8.00 \pm 0.03$ & $8.17 \pm 0.01$ \\
& $20-40$ & $8.48 \pm 0.02$ & $7.87 \pm 0.00$ & $8.08 \pm 0.01$ \\
& $0-30$ & $1.30 \pm 0.06$ & $1.19 \pm 0.06$ & $1.22 \pm 0.04$ \\
\hline
\end{tabular}


(Malus pumila Mill). The plant density is 1,020 plants $\mathrm{ha}^{-1}$, and the distance between the two rows of apple trees was $5 \mathrm{~m}$. The size of the crown of each apple tree was about $3.5 \mathrm{~m}$. Thinning occurred during April and May. The apple orchards in this area are not irrigated, and rainfall is the only source of water. The apple orchard was fertilized twice at a soil depth of $\sim 25 \mathrm{~cm}$ by digging a hole at $1.5 \mathrm{~m}$ from tree row in late March (235 kg N ha ${ }^{-1}$ as urea) and in late June (76.5 $\mathrm{kg} \mathrm{N} \mathrm{ha}^{-1}$ as compound fertilizer) with the hole at $0.5 \mathrm{~m}$ from tree row. In July, weeds were manually hoed up. Several local-produced pesticides and fungicides were foliar spayed two or three times per year to prevent pests and diseases. Annual amounts of active constituents applied were $3 \mathrm{~kg} \mathrm{ha}^{-1}$ of propineb, $2.2 \mathrm{~kg} \mathrm{ha}^{-1}$ of thiophanate-methyl, $0.5 \mathrm{~kg} \mathrm{ha}^{-1}$ of methomyl, $1.8 \mathrm{~kg} \mathrm{ha}^{-1}$ of polyoxin, and $0.4 \mathrm{~kg} \mathrm{ha}^{-1}$ of hexaconazole, respectively. Nitrous oxide emissions were measured by closed chamber methods at: $2.5 \mathrm{~m}$ (hereafter, referred to as D 2.5), $1.5 \mathrm{~m}$ (D 1.5), and $0.5 \mathrm{~m}$ (D 0.5) from the rows of trees. Site D 2.5 was in the middle of the two rows of the apple trees. For each site, three replicate chambers were used. The three sampling sites were selected to investigate the effect of the fertilizer application and the apple tree on $\mathrm{N}_{2} \mathrm{O}$ emission.

\section{Flux measurements}

Nitrous oxide emissions were measured from September 2007 to September 2008 at biweekly intervals except immediately after each fertilizer application and during the freezing and thawing cycles when more measurements were conducted. From January 3 to February 21, 2008 emissions were not measured due to very heavy snow. During this period, conditions were generally not favorable for $\mathrm{N}_{2} \mathrm{O}$ production as the soil temperature was below $-1{ }^{\circ} \mathrm{C}$. Measurements were carried out using static chambers in the midmorning (between 8AM and 12AM). The chambers $(50 \times 50 \times 50 \mathrm{~cm})$ were of transparent PVC fixed to aluminum alloy frames. A buffer pipe $(1.5 \mathrm{~m}, 0.6 \mathrm{~mm}$ o.d. (outer diameter), $0.4 \mathrm{~mm}$ i.d. (inner diameter)) was inserted through the lid to keep the air pressure balanced between the inside and the outside of the chamber. A fan $(12 \mathrm{~V}, 0.5 \mathrm{~A})$, $8 \mathrm{~cm}$ in diameter, was installed on the top wall of each chamber to mix the air when chamber was closed. Permanently positioned chamber bases (length $\times$ width $\times$ height $=$ $50 \times 50 \times 5 \mathrm{~cm}$ ) with water-filled grooves in the upper end were used to ensure gas tightness. During the flux measurements, gas within the chamber was sampled into $0.5 \mathrm{~L}$ polyethylene-coated aluminum bags using a membrane pump at $0,9,18$, and 27 min after the set of the chamber. Nitrous oxide concentrations of samples were analyzed by gas chromatography (Model SP3410, Beijing Analytical Instrument Factory) with an electron capture detector (ECD). The gas samples were loaded into a $2 \mathrm{ml}$ loop connected to a 10-port valve. Both a precolumn ( $2 \mathrm{~m}, 4 \mathrm{~mm}$, o.d. $)$ and an analytical column $(2 \mathrm{~m}, 4 \mathrm{~mm}$, o.d.) were packed with Porapak Q, $80-100$ mesh and hold at $72^{\circ} \mathrm{C}$. Pure nitrogen was used as carrier gas with a flow rate of $30 \mathrm{ml} \mathrm{min}{ }^{-1}$. The temperature values of the ECD and injection port were 390 and $72{ }^{\circ} \mathrm{C}$, respectively. A small amount of $\mathrm{CO}_{2}\left(6 \mathrm{ml} \mathrm{min}{ }^{-1}\right)$ was added into makeup gas of ECD so as to improve the sensitivity and repeatability of ECD. Analytical variability was less than $1 \%$. Nitrous oxide flux was calculated by the rate of the change in the $\mathrm{N}_{2} \mathrm{O}$ concentration in the chamber, estimated as the slope of linear regression between $\mathrm{N}_{2} \mathrm{O}$ concentration and time. Flux rates were discarded if the regression coefficient $\left(r^{2}\right)$ was less than 0.85 .

\section{Soil measurement and analysis}

During each gas sampling, soil temperatures at $10 \mathrm{~cm}$ soil depth, soil moisture $(0-30 \mathrm{~cm})$, and the internal temperature of chambers were simultaneously monitored. The initial and final air temperatures in each chamber were recorded to calculate the fluxes. Soil temperatures were measured with a SN2202 digital thermo detector (Sinan Instrument Plant of Beijing Normal University; Qi et al. 2007). Soil moisture $(0-30 \mathrm{~cm})$ was determined gravimetrically after ovendrying (at $105^{\circ} \mathrm{C}$ for $24 \mathrm{~h}$ ). During the measurements, bulk density was determined monthly, allowing soil WFPS to be calculated from the soil water content values (Merino et al. 2004). Climatic data (precipitation, air temperature, and atmospheric pressure) were obtained from Changwu Agriecological Station of the Loess Plateau located at $100 \mathrm{~m}$ from the experimental site.

At the different phenological stages of the orchard, soil samples at the depths of 0-10, 10-20, and 20-40 cm were taken at five sites near the chamber bases by a 5 -cm-diameter gouge auger. The soil samples were placed in labeled airtight bags and brought to the lab, where they were sieved $(2 \mathrm{~mm})$. Soil mineral nitrogen $\left(\mathrm{NO}_{3}{ }^{-}\right.$and $\left.\mathrm{NH}_{4}{ }^{+}\right)$was extracted with $0.01 \mathrm{M} \mathrm{KCl}$ and measured by colorimetric continuous flow analyzer (SANT++, Skalar Company, the Netherlands; Schloter et al. 2003).

\section{Statistical analysis}

Cumulative $\mathrm{N}_{2} \mathrm{O}$ emissions from each site were calculated by integrating weekly fluxes from the three replicates, assuming a constant flux rate between two gas sampling times. The $\mathrm{N}_{2} \mathrm{O}$ flux was correlated with the measured variables. The relationships among soil and environmental factors, namely soil temperature $(0-10 \mathrm{~cm})$, air temperature, WFPS, and rainfall (in three preceding days) were analyzed by stepwise linear multiple regressions. Comparisons among the three sites were made using a one-way analysis 
of variance. All these statistical analysis were performed by SPSS 13.0 (SPSS Inc., USA). Annual $\mathrm{N}_{2} \mathrm{O}$ emission from this apple orchard soil was estimated from an area after weighting the emission of three sites.

\section{Results}

Soil temperature in the top $10 \mathrm{~cm}$ exhibited a clear seasonal pattern (Fig. 2a). The highest soil temperatures were 27.4, 24.3, and $24.1^{\circ} \mathrm{C}$ at D 2.5, D 1.5 , and D 0.5 sites, respectively, and occurred on June 27, 2008. Soil temperature decreased gradually from $23^{\circ} \mathrm{C}$ in September to below $0^{\circ} \mathrm{C}$ on December 10, 2007. On February 22, 2008, in early spring, soil temperature rose with time.

Soil WFPS over the top $30 \mathrm{~cm}$ soil varied widely in response to rainfall and the growth of the apple trees (Fig. 2b). Generally, the WFPS of the D 2.5 site was higher than the other two sites. At both D 0.5 and D 2.5 sites, the highest WFPS (66.2\% and 70.8\%, respectively) occurred during the freeze-thaw cycles (from February 22 to March $13,2008)$. In both sites, WFPS exceed $60.0 \%$ immediately after a heavy rainfall. At D 1.5 site, WFPS exceeded $60.0 \%$ only immediately after a heavy rainfall.

Soil $\mathrm{NH}_{4}{ }^{+}$and $\mathrm{NO}_{3}{ }^{-}$concentrations in the top $40 \mathrm{~cm}$ of the soil varied widely during the different phonological stages of the orchard at the D 1.5 and D 0.5 sites where fertilizer was applied, whereas, remained relatively constant at the D 2.5 site (Table 2). From April 16 to June 27 2008, soil $\mathrm{NH}_{4}{ }^{+}$and $\mathrm{NO}_{3}{ }^{-}$concentrations of the $\mathrm{D} 2.5$ site were much lower than in the other two sites. During this period, the higher soil $\mathrm{NH}_{4}^{+}$and $\mathrm{NO}_{3}{ }^{-}$concentrations were at all soil depths at D 0.5 site, and this coincided with the active growing phase of the trees. At the D 1.5 site, soil $\mathrm{NH}_{4}^{+}$ concentrations in the $10-20 \mathrm{~cm}$ of soil were generally greater than the concentrations at $0-10$ and $20-40 \mathrm{~cm}$ depth, and soil $\mathrm{NO}_{3}{ }^{-}$concentrations generally increased by increasing soil depth.

Nitrous oxide fluxes varied widely in space and time and were stimulated by nitrogen fertilizer application (Fig. 2c). There was a sharp increase in $\mathrm{N}_{2} \mathrm{O}$ emissions at the D 0.5 site after the application of fertilizer on June 24, 2008. The highest emission, $170 \mu \mathrm{g} \mathrm{N}_{2} \mathrm{O} \mathrm{m} \mathrm{m}^{-2} \mathrm{~h}^{-1}$, occurred 8 days after fertilizer application. In contrast, there was only a small increase in the $\mathrm{N}_{2} \mathrm{O}$ fluxes after applying the urea on March 28, 2008 at the D 1.5 site, with the highest emissions being $73.8 \mu \mathrm{g} \mathrm{N} \mathrm{N}_{2} \mathrm{O} \mathrm{m}{ }^{-2} \mathrm{~h}^{-1} 7$ days after fertilizer application. During freeze-thaw cycles, $\mathrm{N}_{2} \mathrm{O}$ emissions increased in all three sites, with the peak values being $109,60.6$, and $50.9 \mu \mathrm{g} \mathrm{N}_{2} \mathrm{O} \mathrm{m}^{-2} \mathrm{~h}^{-1}$, respectively. At the D 1.5 site, $\mathrm{N}_{2} \mathrm{O}$ fluxes were high in summer 2008 (from June 6 to August 9, 2008), with the maximum value being $177 \mu \mathrm{g} \mathrm{N}_{2} \mathrm{O} \mathrm{m}^{-2} \mathrm{~h}^{-1}$. During the early period of the apple tree defoliation (September 17, 2007), $\mathrm{N}_{2} \mathrm{O}$ emissions were also higher at the D 0.5 and D 1.5 sites than at D 2.5 site. The $\mathrm{N}_{2} \mathrm{O}$ emissions at the D 2.5 site were high from June 6 to August 24, 2008 and during the freeze-thaw period (from February 22 to March 13, 2008), accounting for $34.7 \%$ and $8.61 \%$ of the annual emissions, respectively.

Annual average $\mathrm{N}_{2} \mathrm{O}$ emission rates were highest at the D 0.5 site $\left(48.2 \pm 39.9 \mu \mathrm{g} \mathrm{N}_{2} \mathrm{O} \mathrm{m}^{-2} \mathrm{~h}^{-1}\right)$, lowest at D 2.5 site $\left(31.9 \pm 18.2 \mu \mathrm{g} \mathrm{N}_{2} \mathrm{O} \mathrm{m}^{-2} \mathrm{~h}^{-1}\right)$, and intermediate at $\mathrm{D}$ 1.5 site $\left(36.8 \pm 32.2 \mu \mathrm{g} \mathrm{N}_{2} \mathrm{O} \mathrm{m}^{-2} \mathrm{~h}^{-1}\right.$; Fig. 3). There was a significant difference in the annual average $\mathrm{N}_{2} \mathrm{O}$ emission rates between D 0.5 site and D 2.5 site $(P \leq 0.05$; Fig. 3). As described above, the annual $\mathrm{N}_{2} \mathrm{O}$ emission from this apple orchard soil was estimated from an area by weighting emission at the three sites, and it was $3.22 \mathrm{~kg} \mathrm{~N}_{2} \mathrm{O} \mathrm{ha}{ }^{-1}$ year $^{-1}$. The annual emission factor from the apple orchard soil, uncorrected for background emission, was $0.658 \%$.

The $\mathrm{N}_{2} \mathrm{O}$ fluxes were significantly correlated with soil temperature and ambient air temperature at D 0.5 and $\mathrm{D} 1.5$ sites ( $P \leq 0.05$ and $P \leq 0.01$, respectively). At the $\mathrm{D} 2.5$ site, there was only significant correlation between $\mathrm{N}_{2} \mathrm{O}$ fluxes and ambient air temperature $(P \leq 0.05)$. There was no significant correlation between $\mathrm{N}_{2} \mathrm{O}$ fluxes and WFPS. There was a significant correlation between the $\mathrm{N}_{2} \mathrm{O}$ flux and concentrations of soil $\mathrm{NO}_{3}{ }^{-}$at the $20-0 \mathrm{~cm}$ depth at the D 0.5 site $(P \leq 0.01)$. The multiple regression of $\mathrm{N}_{2} \mathrm{O}$ flux with soil temperature at $0-10 \mathrm{~cm}$, air temperature, WFPS, and accumulated rainfall in three anteceding days showed that air temperature could be identified as the only key factor determining the temporal variability of $\mathrm{N}_{2} \mathrm{O}$ flux at each sites and accounted for $19 \%, 24 \%$, and $20 \%$ of the temporal variation in sites D $2.5(P<0.1), \mathrm{D} 1.5(P<$ $0.002)$, and D $0.5(P<0.006)$, respectively.

\section{Discussion}

The fluxes of $\mathrm{N}_{2} \mathrm{O}$ from terrestrial ecosystem are more uncertain than that of other greenhouse gases (such as $\mathrm{CO}_{2}$ and $\left.\mathrm{CH}_{4}\right)$. The coefficients of variations $(\mathrm{CVs})$ of $\mathrm{N}_{2} \mathrm{O}$ emission for the three replicates were $0.27,0.23$, and 0.25 at sites D 2.5, D 1.5, and D 0.5, respectively. The seasonal CVs were in ranges of $3-66 \%, 1-53 \%$, and $3-61 \%$ at sites D 2.5, D 1.5, and D 0.5, respectively.

Soil WFPS at all sites was always below $60.0 \%$ except during freeze-thaw cycle and immediately after heavy rainfall. The coarse texture and the low water retention capacity of soils limited the possibility of the formation of anaerobic microsites, where $\mathrm{N}_{2} \mathrm{O}$ production could take place (Castaldi et al. 2004). Nitrous oxide emission is affected by soil moisture (Ciarlo et al. 2008), and indeed higher $\mathrm{N}_{2} \mathrm{O}$ emission occurred after raining in this study. Previous studies have indicated that denitrification rates 
Fig. 2 Soil temperature (0-10 cm; a), WFPS $(0-30 \mathrm{~cm}$; b), and $\mathrm{N}_{2} \mathrm{O}$ fluxes during the study period in the apple orchard. Arrows indicate the timing of fertilizer application (c)

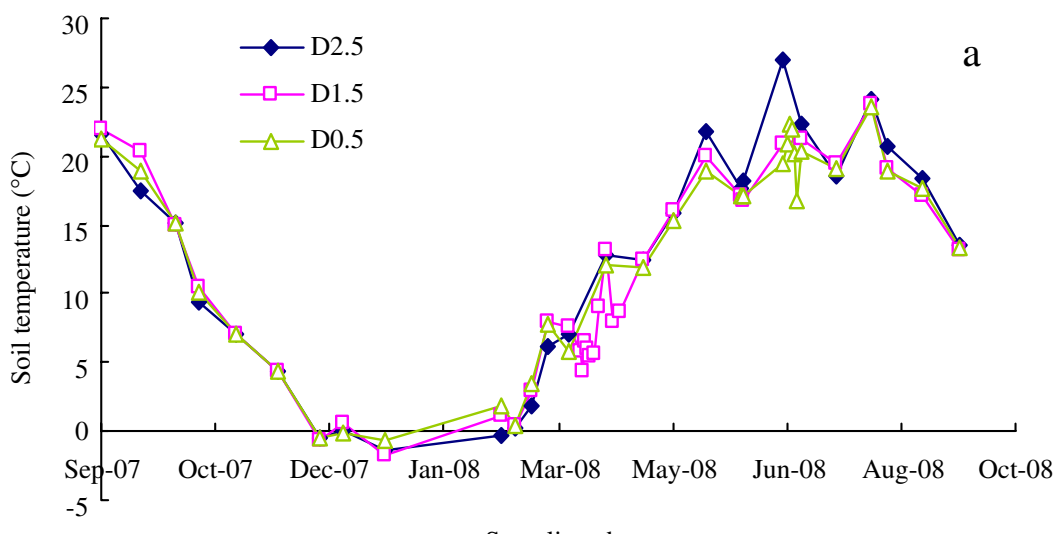

Sampling date
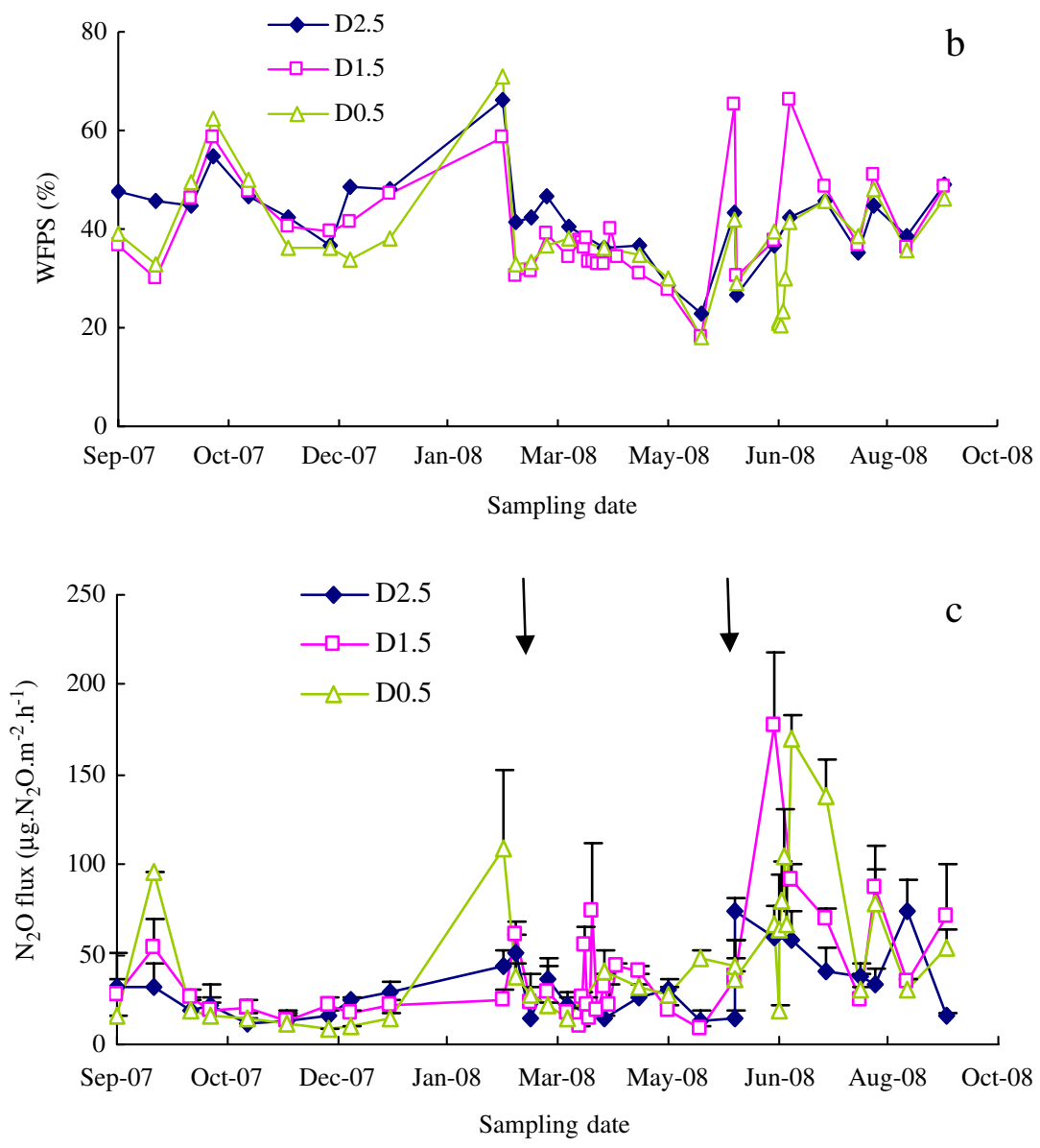

increased rapidly when WFPS exceeds 63\%, whereas nitrification was the dominant source of $\mathrm{N}_{2} \mathrm{O}$ when the WFPS was in the range of 30-70\% (Davidson et al. 2000; Ciarlo et al. 2008; Zhang and Han 2008). Therefore, it seems reasonable to hypothesize that nitrification is the main source of $\mathrm{N}_{2} \mathrm{O}$ in this region. The study area showed a clear seasonal pattern in air temperature and soil temperature, and $\mathrm{N}_{2} \mathrm{O}$ emissions from the three sites were significantly correlated with the air temperature. Dong et al. (2001) also found that there was a significant correlation between $\mathrm{N}_{2} \mathrm{O}$ fluxes and ambient air temperature in their cultivated soils of the North China Plain.

The urea applied in soil is hydrolyzed to $\mathrm{NH}_{4}{ }^{+}$, which is the substrate for nitrification, so that $\mathrm{N}_{2} \mathrm{O}$ fluxes can increase after urea fertilization (Barton et al. 2007). However, $\mathrm{N}_{2} \mathrm{O}$ fluxes varied widely in response to the two $\mathrm{N}$ fertilizer application and were usually greater after the fertilization in June than after the fertilization in March because in late June, the soil conditions were more conducive for $\mathrm{N}_{2} \mathrm{O}$ production than during the late March 
Table 2 Soil nitrate and ammonium content during the different phonological stages of the apple orchard

\begin{tabular}{|c|c|c|c|c|c|c|c|c|}
\hline \multirow[t]{2}{*}{ Site } & \multirow{2}{*}{$\begin{array}{l}\text { Concentration } \\
\left(\mu g g^{-1}\right)\end{array}$} & \multirow{2}{*}{$\begin{array}{l}\text { Soil } \\
\text { depth (cm) }\end{array}$} & \multicolumn{6}{|l|}{ Sampling date } \\
\hline & & & $26 / 10 / 2007$ & 04/03/2008 & $16 / 04 / 2008$ & 09/05/2008 & $28 / 06 / 2008$ & 01/08/2008 \\
\hline \multirow[t]{6}{*}{ D 2.5} & $\mathrm{NH}_{4}^{+}$ & $0-10$ & $7.78 \pm 0.650$ & $4.82 \pm 0.0625$ & $25.4 \pm 1.27$ & $20.0 \pm 3.42$ & $3.24 \pm 0.382$ & $3.00 \pm 0.458$ \\
\hline & & $10-20$ & $4.20 \pm 0.688$ & $2.39 \pm 0.0462$ & $50.9 \pm 3.26$ & $10.6 \pm 1.21$ & $2.65 \pm 0.259$ & $3.17 \pm 0.263$ \\
\hline & & $20-40$ & $4.60 \pm 0.625$ & $4.86 \pm 0.625$ & $16.7 \pm 2.35$ & $11.3 \pm 1.67$ & $2.36 \pm 0.0630$ & $3.46 \pm 0.925$ \\
\hline & $\mathrm{NO}_{3}^{-}$ & $0-10$ & $15.1 \pm 15.1$ & $12.1 \pm 0.750$ & $4.55 \pm 2.09$ & $22.6 \pm 1.39$ & $16.7 \pm 1.02$ & $3.14 \pm 0.915$ \\
\hline & & $10-20$ & $34.5 \pm 26.6$ & $11.6 \pm 6.44$ & $5.16 \pm 3.11$ & $9.55 \pm 1.76$ & $8.10 \pm 0.582$ & $1.68 \pm 0.922$ \\
\hline & & $20-40$ & $46.9 \pm 23.5$ & $15.7 \pm 0.813$ & $3.26 \pm 0.876$ & $8.20 \pm 3.47$ & $7.71 \pm 4.85$ & $4.44 \pm 0.198$ \\
\hline \multirow[t]{6}{*}{ D 1.5} & $\mathrm{NH}_{4}^{+}$ & $0-10$ & $13.6 \pm 11.7$ & $4.69 \pm 1.50$ & $42.9 \pm 4.79$ & $323 \pm 20.7$ & $1.99 \pm 0.438$ & $3.54 \pm 0.0686$ \\
\hline & & $10-20$ & $17.4 \pm 13.1$ & $3.98 \pm 1.00$ & $85.1 \pm 6.27$ & $487 \pm 12.4$ & $2.48 \pm 0.319$ & $3.76 \pm 0.207$ \\
\hline & & $20-40$ & $12.6 \pm 19.4$ & $5.35 \pm 0.313$ & $11.4 \pm 1.37$ & $59.3 \pm 10.2$ & $2.07 \pm 0.266$ & $3.36 \pm 0.461$ \\
\hline & $\mathrm{NO}_{3}^{-}$ & $0-10$ & $38.2 \pm 27.1$ & $12.0 \pm 3.69$ & $3.46 \pm 0.249$ & $147 \pm 24.7$ & $15.6 \pm 7.94$ & $9.36 \pm 1.30$ \\
\hline & & $10-20$ & $69.4 \pm 12.4$ & $11.2 \pm 1.25$ & $3.67 \pm 0.364$ & $279 \pm 43.0$ & $69.1 \pm 6.31$ & $8.94 \pm 0.621$ \\
\hline & & $20-40$ & $459 \pm 14.0$ & $52.2 \pm 1.12$ & $1.39 \pm 0.247$ & $375 \pm 42.4$ & $215 \pm 5.12$ & $33.5 \pm 6.91$ \\
\hline \multirow[t]{6}{*}{ D 0.5} & $\mathrm{NH}_{4}^{+}$ & $0-10$ & $10.1 \pm 3.68$ & $4.51 \pm 0.875$ & $48.4 \pm 6.38$ & $759 \pm 2.39$ & $120 \pm 4.78$ & $3.47 \pm 0.140$ \\
\hline & & $10-20$ & $12.4 \pm 8.17$ & $3.40 \pm 0.688$ & $153 \pm 9.24$ & $1114 \pm 79.8$ & $229 \pm 7.74$ & $2.79 \pm 0.300$ \\
\hline & & $20-40$ & $10.4 \pm 6.31$ & $3.93 \pm 0.563$ & $69.3 \pm 4.45$ & $639 \pm 100$ & $154 \pm 13.2$ & $2.74 \pm 0.400$ \\
\hline & $\mathrm{NO}_{3}^{-}$ & $0-10$ & $6.31 \pm 0.736$ & $9.15 \pm 1.69$ & $222 \pm 31.5$ & $36.5 \pm 7.68$ & $65.8 \pm 9.19$ & $4.32 \pm 0.631$ \\
\hline & & $10-20$ & $18.7 \pm 8.00$ & $11.3 \pm 0.813$ & $66.0 \pm 23.1$ & $11.5 \pm 1.92$ & $89.5 \pm 8.66$ & $2.09 \pm 0.329$ \\
\hline & & $20-40$ & $15.0 \pm 1.48$ & $9.68 \pm 0.688$ & $2.88 \pm 0.855$ & $9.83 \pm 2.76$ & $177 \pm 8.38$ & $2.88 \pm 1.27$ \\
\hline
\end{tabular}

since soil temperature was generally higher than $20.0^{\circ} \mathrm{C}$, and the top soil was subjected to regular wetting and drying cycles (Davidson et al. 1993; Dobbie et al. 1999; Du et al. 2006).

On June 8, 2008, we found that the greatest fluxes of $\mathrm{N}_{2} \mathrm{O}$ at D 2.5 site occurred after the first summer rainfall of more than $10 \mathrm{~mm}$ (Fig. 2c). At both D 1.5 and D 0.5 sites, the greatest fluxes of $\mathrm{N}_{2} \mathrm{O}$ occurred on the second day of the continuous rainfall probably because the effects of the rainfall on soil moisture differed among sites beneath the apple trees.

In temperate climates, freeze-thaw cycles can increase $\mathrm{N}_{2} \mathrm{O}$ emission rates (Muller et al. 2002). In this study, the pulse of $\mathrm{N}_{2} \mathrm{O}$ emission occurred in early spring (Fig. 2c), but it lasted shortly and contributed little to the annual emission. Probably there was no enough $\mathrm{N}_{2} \mathrm{O}$ accumulation beneath the frozen soil layers as the conditions (no input of organic matter and $\mathrm{N}$ fertilizer during the winter to soil) were not conducive for $\mathrm{N}_{2} \mathrm{O}$ production. On the other hand, during the middle and the late of the freeze-thaw cycles, the apple trees in the bud phase began to compete with soil microorganisms for available soil N (Groffman et al. 2006).

In this study, the proportion of the applied $\mathrm{N}$ fertilizer emitted as $\mathrm{N}_{2} \mathrm{O}-\mathrm{N}$ was $0.658 \%$ by including the contribution of the background emission and was about 1.90 times less than the default value provided by the IPCC (1997), 1.40 times less than the direct emission factor determined by $\mathrm{Lu}$ et al. (2006) for agricultural soils in China, and 32.9 times higher than the only available emission factor for the rain-fed agricultural soils in semiarid region reported by Barton et al. (2007). Although both studies have been conducted in agricultural soils in rain-fed semiarid regions, the climate patterns differed with those of our study, for example, our study site had an annual rainfall of $584 \mathrm{~mm}$ and was subjected to freeze-thaw cycles, whereas the site of Barton et al. (2007) has annual precipitation of $358 \mathrm{~mm}$ and was not subjected to freeze-thaw cycles. In addition both sites had different soil types, different crops, and different tillage and nitrogen fertilizer managements, and the emission factor reported by Barton et al. (2007) was

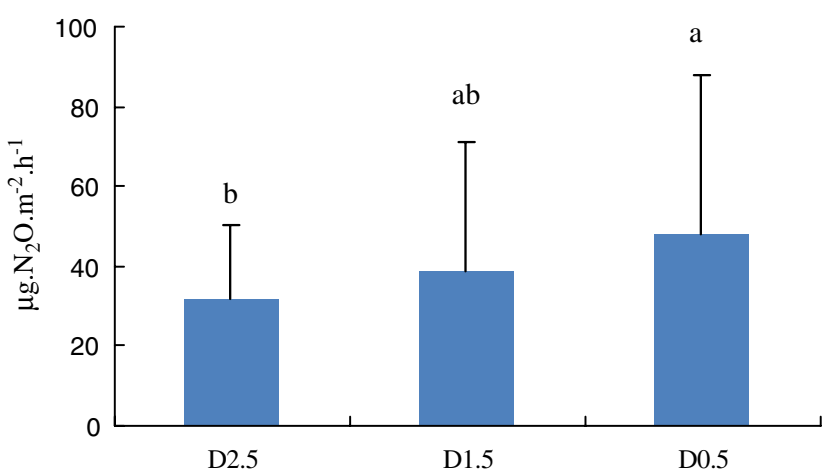

Fig. 3 Annual average $\mathrm{N}_{2} \mathrm{O}$ emission rates during the study period at the three sites. Different letters indicate the significant difference $(P \leq 0.05)$ in $\mathrm{N}_{2} \mathrm{O}$ emission rates among the three sites 
corrected for background emission. In order to obtain a robust mean emission factor for semiarid agriculture, multiyear and automated measurements at several typical sites are needed.

The extension of the apple orchard area in Loss Plateau of China is about $7.83 \times 10^{5}$ ha (including Shaanxi, Shanxi, Qinghai, Ningxia Gansu Provinces). The annual (377 days) $\mathrm{N}_{2} \mathrm{O}$ emission from the apple orchards in this region was estimated to be $2.52 \times 10^{9} \mathrm{~g} \mathrm{~N}_{2} \mathrm{O}$, accounting for about $0.92 \%$ of the total $\mathrm{N}_{2} \mathrm{O}$ emissions from Chinese croplands (Zheng et al. 2004). Assuming that the total area of apple orchards in China is $1.89 \times 10^{6}$ ha, we estimated an overall $\mathrm{N}_{2} \mathrm{O}$ emission from the apple orchards of about $6.08 \times$ $10^{9} \mathrm{~g} \mathrm{~N}_{2} \mathrm{O}$, which accounted for about $2.21 \%$ of the total $\mathrm{N}_{2} \mathrm{O}$ emissions from Chinese croplands (Zheng et al. 2004).

\section{Conclusions}

The year measurements of $\mathrm{N}_{2} \mathrm{O}$ from an apple orchard soils in the semiarid Loess Plateau (China) indicated that the apple orchards are a potential source of $\mathrm{N}_{2} \mathrm{O}$ emission with high $\mathrm{N}_{2} \mathrm{O}$ emission rates in the hot-humid summer and low rates in the cold-dry winter. Pulses of $\mathrm{N}_{2} \mathrm{O}$ emissions occurred after $\mathrm{N}$ fertilizer application, summer rainfall events, and during freeze-thaw cycle. These short-term pulses contributed significantly to the annual $\mathrm{N}_{2} \mathrm{O}$ emission and should be captured during field measurements of $\mathrm{N}_{2} \mathrm{O}$ emission. Multiple automated chambers system can provide a good approach for measuring $\mathrm{N}_{2} \mathrm{O}$ with high temporal resolution and possibilities of having more replicates and under all meteorological conditions.

Over one third $(37.1 \%)$ of the annual $\mathrm{N}_{2} \mathrm{O}$ emission occurred in the summer, when soil temperature was generally higher than $20^{\circ} \mathrm{C}$, with greater levels of available carbon and nitrogen and more frequent dry-wet-dry cycles; these conditions were favorable to $\mathrm{N}_{2} \mathrm{O}$ production. The results of stepwise multiple linear regression showed that air temperature was the only key factor influencing the temporal variation in $\mathrm{N}_{2} \mathrm{O}$ flux. Cumulative annual $\mathrm{N}_{2} \mathrm{O}$ emissions from soil were estimated to be $3.22 \mathrm{~kg} \mathrm{~N}_{2} \mathrm{O} \mathrm{ha}^{-1}$ year $^{-1}$, and the annual emission factor uncorrected for background emission was $0.658 \%$. This work has confirmed the findings of Barton et al. (2007), that the proportion of $\mathrm{N}$ fertilizer lost from cropland in semiarid climates is likely much lower than the global average.

Acknowledgment This study was supported by the National Science Foundation of China (40321101) and Ministry of Science and Technology (2002CB412503). The authors would like to thank Meiling Chen and Yucheng Li for their technical assistance in the field. We are very grateful to the editor and two anonymous reviewers for giving helpful comments and revision suggestions.

\section{References}

Barton L, Kiese R, Gatter D, Butterbach-Bahl K, Buck R, Hinz C, Murphy DV (2007) Nitrous oxide emissions from a cropped soil in a semi-arid climate. Glob Chang Biol 0:177-192

Bouwman AF (1998) Nitrogen oxides and tropical agricultural. Nature 392:866-867. doi:10.1038/31809

Castaldi S, Aragosa D, Grace J, Nikonova N, Montes R, San Jose JJ (2004) Nitrous oxide and methane fluxes from soils of the Orinoco savanna under different land uses. Glob Chang Biol 10:1947-1960. doi:10.1111/j.1365-2486.2004.00871.x

Ciarlo E, Conti M, Bartoloni N, Rubio G (2008) Soil N2O emissions and $\mathrm{N} 2 \mathrm{O} /(\mathrm{N} 2 \mathrm{O}+\mathrm{N} 2)$ ratio as affected by different fertilization practices and soil moisture. Biol Fertil Soils 44:991-995

Davidson EA, Matson PA, Vitousek PM, Riley R, Dunkin K, GarciaMendez G, Maass JM (1993) Processes regulating soil emissions of $\mathrm{NO}$ and $\mathrm{N}_{2} \mathrm{O}$ in a seasonally dry forest. Ecol 74:130-139. doi:10.2307/1939508

Davidson EA, Keller M, Erickson HE, Verchot LV, Veldkamp AE (2000) Testing a conceptual model of soil emission of nitrous and nitric oxides. Biosci 50:667-680. doi:10.1641/0006-3568(2000) 050[0667:TACMOS]2.0.CO;2

Dobbie KE, Smith KA (2003) Nitrous oxide emission factors for agricultural soils in Great Britain: the impact of soil water-filled pore space and other controlling variables. Glob Chang Biol 9:204-218

Dobbie KE, McTaggart IP, Smith KA (1999) Nitrous Oxide emission from intensive agricultural systems: variation between crops and seasons, key driving variables, and mean emission factors. J Geophys Res 104:26891-26899. doi:10.1029/1999JD900378

Dong Y, Scharffe D, Qi YC, Peng GB (2001) Nitrous oxide emissions from cultivated soils in the North China Plain. Tellus B 53:1-9

Du R, Lu DR, Wang GC (2006) Diurnal, seasonal, and inter-annual variations of $\mathrm{N}_{2} \mathrm{O}$ fluxes from native semi-arid grassland soils of inner Mongolia. Soil Biol Biochem 38:3474-3482. doi:10.1016/ j.soilbio.2006.06.012

Groffman PM, Hardy JP, Driscoll CT, Fahey TJ (2006) Snow depth, soil freezing, and fluxes of carbon dioxide, nitrous oxide and methane in a northern hardwood forest. Glob Chang Biol 12:1748-1760. doi:10.1111/j.1365-2486.2006.01194.x

Hoagland L, Carpentier-Boggs L, Granatstein D, Mazzola M, Smith J, Peryea F, Reganold JP (2008) Orchard floor management on nitrogen fertility and soil biological activity in a newly established organic apple orchard. Biol Fertil Soils 45:11-18

Intergovernmental Panel on Climate Change (1997) Revised 1996 IPCC Guidelines for National Greenhouse Gas Inventories. IPCC/OECD/IEA, Paris

$\mathrm{Lu}$ Y, Huang Y, Zou J, Zheng X (2006) An inventory of $\mathrm{N}_{2} \mathrm{O}$ emission from agriculture in China using precipitation-rectified emission factor and background emission. Chemosphere 65:1915-1924. doi:10.1016/j.chemosphere.2006.07.035

Martin RE, Asner GP, Ansley RJ, Mosier AR (2003) Effects of woody vegetation encroachment on soil nitrogen oxide emissions in a temperate savanna. Ecol Appl 4:897-910. doi:10.1890/10510761(2003)13[897:EOWVEO]2.0.CO;2

Merino A, Perez-Batallon P, Macias F (2004) Responses of soil organic matter and greenhouse gas fluxes to soil management and land uses changes in a humid temperate region of southern European. Soil Biol Biochem 36:917-925

Mosier AR, Duxbury JM, Freney JR, Heinmeyer O, Minami K (1996) Nitrous oxide emission from agricultural fields: assessment, measurement and mitigation. Plant Soil 181:95-108. doi:10.10 07/BF00011296

Muller C, Martin M, Stevens RJ, Laughlin RJ, Kammann C, Ottow JCG, Jager HJ (2002) Processes leading to $\mathrm{N}_{2} \mathrm{O}$ emission in 
grassland soil during freezing and thawing. Soil Biol Biochem 34:1325-1331. doi:10.1016/S0038-0717(02)00076-7

Qi YC, Dong YS, Liu JY, Domrose M, Geng YB, Liu LX, Liu XR, Yong $\mathrm{XH}$ (2007) Effect of the conversion of grassland to spring wheat field on the $\mathrm{CO}_{2}$ emission characteristics in Inner Mongolia, China. Soil Tillage Res 94:310-320. doi:10.1016/j.still.2006.08.008

Schloter M, Bach HJ, Metz S, Sehy U, Munch JC (2003) Influence of precision farming on the microbial community structure and functions in nitrogen turnover. Agric Ecosyst Environ 98:295-304

Stehfest E, Bouwman L (2006) $\mathrm{N}_{2} \mathrm{O}$ and $\mathrm{NO}$ emission from agricultural fields and soils under natural vegetation: summarizing available measurement data and modeling of global annual emissions. Nutr Cycl Agroecosyst 74:207-228

Weitz AM, Linder E, Frolking S, Crill PM, Keller M (2001) $\mathrm{N}_{2} \mathrm{O}$ emission from humid tropical agricultural soils: effects of soil moisture, texture and nitrogen availability. Soil Biol Biochem 33:1077-1093. doi:10.1016/S0038-0717(01)00013-X

Wu FQ, Liu HB, Sun BS, Wang J, Gale WJ (2008) Net primary production and nutrient cycling in an apple orchard - annual crop system in the Loess Plateau, China: a comparison of Qinguan apple, Fuji apple, corn and millet production subsystems. Nutr Cycl Agroecosyst 81:95-105. doi:10.1007/s10705-007-9163-x

Zhang JF, Han XG (2008) $\mathrm{N}_{2} \mathrm{O}$ emission from the semi-arid ecosystem under mineral fertilizer (urea and superphosphate) and increased precipitation in northern China. Atmos Environ 42:291-302. doi:10.1016/j.atmosenv.2007.09.036

Zheng X, Han S, Huang Y, Wang Y, Wang M (2004) Re-quantifying the emission factors based on field measurements and estimating the direct $\mathrm{N}_{2} \mathrm{O}$ emission from Chinese croplands. Glob Biogeochem Cycles 18:GB2018 